\title{
Evaluating the potential of IASI ozone observations to constrain simulated surface ozone concentrations
}

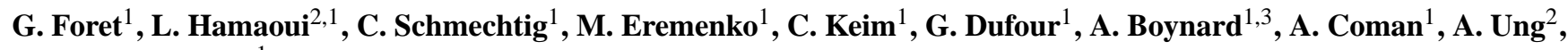 \\ and M. Beekmann ${ }^{1}$ \\ ${ }^{1}$ Université Paris 12 et 7, UMR CNRS/INSU 7583, Laboratoire Interuniversitaire des Systèmes Atmosphériques/IPSL, \\ Créteil, France \\ ${ }^{2}$ Institut National de l'Environnement Industriel et des Risques, Chronic Risks Division, Parc Technologique Alata, \\ Verneuil-en-Halatte, France \\ ${ }^{3}$ UPMC Université Paris 06, UMR CNRS/INSU 8190, Laboratoire Atmosphères, Milieux, Observations Spatiales/IPSL, \\ Paris, France
}

Received: 27 February 2009 - Published in Atmos. Chem. Phys. Discuss.: 4 June 2009

Revised: 16 October 2009 - Accepted: 25 October 2009 - Published: 6 November 2009

\begin{abstract}
A tracer study has been performed for two summers in 2003 and 2004 with a regional chemistry-transport model in order to evaluate the potential constraint that tropospheric ozone observations from nadir viewing infrared sounders like IASI or TES exert on modelled near surface ozone. As these instruments show high sensitivity in the free troposphere, but low sensitivity at ground, it is important to know how much of the information gained in the free troposphere is transferred to ground through vertical transport processes. Within the European model domain, and within a time span of 4 days, only ozone like tracers initialised in vertical layers above $500 \mathrm{hPa}$ are transported to the surface. For a tracer initialised between 800 and $700 \mathrm{hPa}$, seven percent reaches the surface within one to three days, on the average over the European model domain but more than double over the Mediterranean Sea. For this region, trajectory analysis shows that this is related to strong subsident transport. These results are confirmed by a second tracer study taking into account averaging kernels related to IASI retrievals, indicating the potential of these measurements to efficiently constrain surface ozone values.
\end{abstract}

\section{Introduction}

Since many years, ozone is one of the main targets of pollution control policy. Due to its harmful character for human health but also for vegetation and materials, many efforts are made to monitor and control its concentrations. This is one of the objectives of the Global Monitoring for Environment

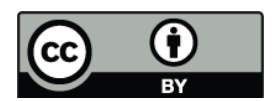

Correspondence to: G. Foret (foret@lisa.univ-paris12.fr) and Security (GMES) project (http://www.gmes.info), which aims at developing integrated observation and modeling systems to inform population about exposure to sporadic high pollutant levels, and to settle a scientific basis for constructing mitigation policies to avoid such episodes and long-term exposure to high-level ozone concentrations.

Regional chemistry-transport models (RCTM) will be part of such systems. Performances of these models to simulate ozone concentrations have been significantly increased in recent years. For example, the PREVAIR platform (www.prevair.org) uses two of such models (CHIMERE and MOCAGE) for operational forecast of ozone and particulate matter concentrations (Honoré et al., 2008) two days in advance. In this framework, ozone concentrations simulated with the CHIMERE model have been compared to ground-based measurements for three spring/summer periods between 2004 and 2006. Honoré et al. (2008) showed that the mean model bias of daily ozone maxima was mostly under $5 \mu \mathrm{g} / \mathrm{m}^{-3}$, RMSE (root mean square error) was generally less than $20 \mu \mathrm{g} / \mathrm{m}^{-3}$ and temporal correlation was more than 0.8 on average over Western Europe.

Despite these satisfying results, uncertainties remain in such models, either concerning input data or the model formulation itself. This is the case for primary pollutant emissions, transport (especially turbulence), chemistry (representation of VOC's), photolysis rates (impact of aerosols and clouds), wet and dry deposition, and chemical boundary conditions. This is illustrated by the difficulties of the model to correctly predict exceedence of information or alert thresholds for ozone (180 and $240 \mu \mathrm{g} / \mathrm{m}^{3}$ respectively) (Honoré et al., 2008). Considering socio-economical implications of decisions based on such predictions, the model reliability should be improved. 
Data assimilation using surface ozone and other surface measurements has shown to partly correct model deficiencies (Blond and Vautard, 2004). However, these studies made evident that the set of available surface observations (concentrated in this case over Western Europe) is a limitation, and that added information decays quickly in time (at a time scale of about half a day). This can be partly explained by the rapid advection of fresh air masses from aloft or from outside the considered regional domain. For example, Fiore et al. (2002) have estimated that 20-45 ppbv of boundary layer (PBL) ozone in the US was transported from outside the continental PBL (either through subsidence or horizontal advection).

Satellite derived ozone profiles could be an important data source on regional ozone burdens complementary to surface ozone observations. This is especially true for the new generation of nadir viewing infrared (IR) sounders with high spectral resolution that provide tropospheric ozone with about one to two independent pieces of information in the vertical (IMG, Coheur et al., 2005; TES, Beer, 2006; IASI, Clerbaux et al., 2007). In case of the IASI instrument, the sampling frequency is twice daily, the horizontal resolution of pixels below the satellite trace is less than $20 \mathrm{~km} \times 20 \mathrm{~km}$. Lower tropospheric $(0-6 \mathrm{~km})$ ozone partial columns retrieved from IASI observations showed good comparison with collocated ozone sonde measurements (mean bias $~ 3 \%$, RMS about $10 \%$ ) even for the most northern stations where temperature conditions are less favourable for ozone retrieval (Eremenko et al., 2008). However, IR nadir viewing instruments exhibit weak sensitivity to surface and to PBL ozone concentrations, but large sensitivity to free tropospheric ozone (Eremenko et al., 2008; Parrington et al., 2008). As a consequence, they are very valuable to follow the evolution of free tropospheric ozone, but their capacity to act as a constraint for modelling surface ozone, for example in the frame of data assimilation, needs to be carefully assessed. Parrington et al. (2008) assimilated tropospheric ozone profiles derived from TES instrument into two global chemistry-transport models and showed that such data could greatly help to improve simulations of free tropospheric ozone. Moreover, they demonstrated that the assimilation of TES ozone profiles in the GEOS-CHEM model had an impact on simulated ozone surface concentrations over the United States due to an increase of downward ozone fluxes in their simulation, but they do not obtain an overall improvement of surface ozone concentrations. Boisgontier et al. (2008) also underlined the potential of assimilating simulated IASI-like ozone observations to better constrain surface ozone concentrations in a regional air quality model. However, we should keep in mind the multiple error sources affecting simulations of boundary layer ozone (primary pollutants emissions, representation of the PBL dynamics, chemistry...). This implies that the correction of simulated free tropospheric ozone and associated downward fluxes allows only a partial correction of the surface ozone in the model.
In case of mid-latitude polluted areas (Europe, United States), summertime surface ozone concentrations are highest when stable anti-cyclonic conditions allow for enhanced photochemical ozone production. In such conditions, high surface temperatures occur associated with an increase in PBL height. Sensitivity of satellite instruments to boundary layer ozone is then increased by a sharper thermal contrast between surface and lowest level of atmosphere (Deeter et al., 2007) and by the fact that instrumental sensitivity increases with altitude. This sensitivity of the satellite measurements to high ozone concentrations in the lower free troposphere has been illustrated by Eremenko et al. (2008) during the 2007 summer European heat wave. Moreover, under subsident meteorological conditions, surface air masses efficiently sampled by the satellite are transported downward. This is the case during summer over Southern Europe (Mediterranean Basin) where persistent anticyclonic conditions are present due to a descending branch of the Hadley circulation (Ziv et al., 2004; Kalabokas et al., 2008). In summer, the subtropical ridge extends to the North-East and the Mediterranean area (especially the Western basin) is under the subsiding influence of the Azores anticyclone (Xoplaki, 2000). Under such conditions, a significant part of boundary layer air masses originates from the European free troposphere (Lelieveld et al., 2002; Traub et al., 2003). Several previous studies have paid attention to the tropospheric vertical mixing processes to address ventilation of PBL pollutants into the free troposphere (Sinclair et al., 2008), by warm conveyor belt (Kowol-Santen et al., 2001), cloud and mountain venting (Cotton et al., 1995; Henne et al., 2005), land-sea exchange processes (Foret et al., 2006; Dacre et al., 2007) or deep convection (Doherty et al., 2005; Lawrence and Rasch, 2005). However, only few have considered the reverse problem (Fiore et al., 2002; Parrington et al., 2009), i.e. the downward transport from the free troposphere to the PBL, especially over Europe (Traub et al., 2003).

In this paper, we investigate the potential of observations from nadir viewing IR sounders such as IASI to be used as a constraint for modelled surface ozone. As said before, given the lack of sensitivity of these instruments to the surface, we need to assess to which extent information delivered in the free troposphere where the instrument's sensitivity is high, can affect surface ozone due to subsidence of free tropospheric air masses and/or by rising of the PBL up to an altitude where IASI becomes more and more sensitive. To this aim, we will introduce quasi inert tracers into the state-ofthe-art RCTM CHIMERE and analyse their downward transport over the European domain, as a function of the meteorological situation. In order to obtain more robust results, two different summer seasons (2003 and 2004) are considered. We will also use a specific tracer which is representative for the information content provided by IASI-like measurements. Results presented in this paper will give an upper limit for the benefit of assimilating IASI or TES like satellite observations into a regional CTM, for improving surface 
ozone modelling. This study focuses on aspects of vertical transmission of information, since this will be a key issue for the success of data assimilation.

The paper is organised as follow. In Sect. 2, we present the CHIMERE model and the general configuration of the simulations; then methodology and results of the passive tracer experiment are presented and discussed in Sect. 3; the description of the methodology and results of the IASI-like tracer experiment follows in Sect. 4; Sect. 5 gives conclusions and perspectives.

\section{CHIMERE model}

To simulate ozone as well as inert tracer concentrations (the letter being described in Sect. 3), we use the CHIMERE RCTM. The version that is used here has been described in Bessagnet et al. (2008) and more details concerning the parameterization used can be obtained from www.lmd. polytechnique.fr/chimere. This state-of-the-art model allows simulating a wide variety of gaseous pollutants $\left(\mathrm{O}_{3}, \mathrm{NO}_{\mathrm{x}}\right.$, $\mathrm{SO}_{2}, \mathrm{CO}, \mathrm{VOC} \ldots$ ) as well as airborne particulate matter (inorganic ions, secondary organic compounds, primary emissions, mineral dust...). It has been used for numerous air quality studies dealing with gaseous and/or particulate pollution (i.e. Vautard et al., 2005; Coll et al., 2005; Hodzic et al., 2006; Deguillaume et al., 2008). As said before, it is used operationally within the PREVAIR platform (www.prevair.org, Rouil et al., 2009) to produce ozone, $\mathrm{NO}_{\mathrm{x}}$ and particulate matter short-term forecasts and analyses at continental scale.

For this work, the simulation is set up over a large western European domain (ranging from $10^{\circ} \mathrm{W}$ to $22^{\circ} \mathrm{E}$ and from $35^{\circ} \mathrm{N}$ to $58^{\circ} \mathrm{N}$ ) as indicated in Fig. 1. To cover this domain, $3082(67 \times 46)$ horizontal grid points with $0.5^{\circ} \times 0.5^{\circ}$ (around $50 \mathrm{~km} \times 50 \mathrm{~km}$ ) horizontal resolution are necessary. 17 vertical levels are defined following an hybrid $(\sigma, \mathrm{p})$ scheme; their thickness varies from $40 \mathrm{~m}$ in the surface layer to about $1 \mathrm{~km}$ in the free troposphere. Top pressure and altitude of each level are indicated in Table 1 for a grid point at sea level.

We use LMDz-INCA monthly climatology (Hauglustaine et al., 2004) to impose gaseous concentrations at the domain boundaries (top and boundary conditions). Primary pollutant emissions are based on the EMEP 2003 inventory (Vestreng et al., 2005). Meteorological fields (pressure, temperature, wind components, relative humidity, liquid water content and precipitation) are calculated off-line by the Integrated Forecasting System of the European Centre for Medium-Range Weather Forecasts $(\mathrm{ECMWF})$ at a $0.5^{\circ} \times 0.5^{\circ}$ horizontal resolution: analyses at 00:00 UT and 12:00 UT are used and complemented with 3-hourly forecasts. In this type of data, vertical mixing processes linked to synoptic scale features and to frontal activity are taken into account. However, smaller scale processes like shallow cloud and mountain venting, land-sea breezes are not fully resolved in these fields. Vertical fluxes related to deep convection are rediagnosed in

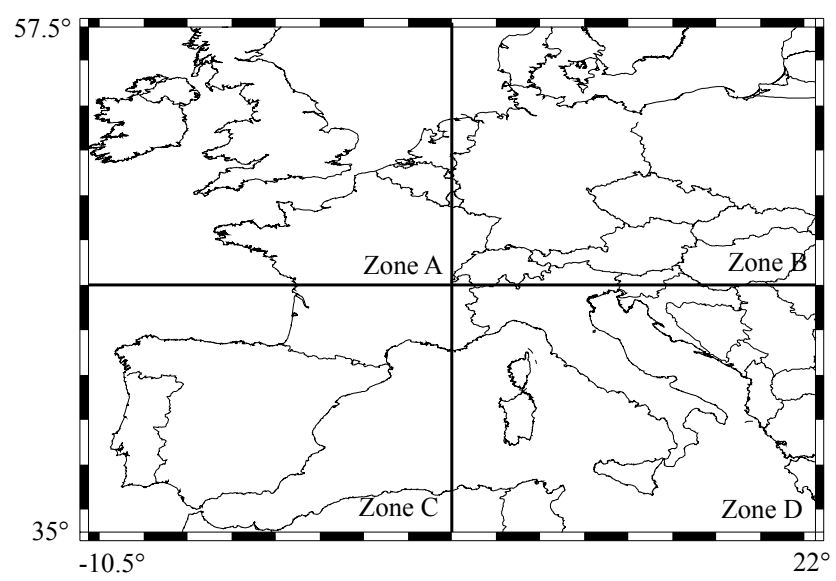

Fig. 1. Geographical map of the simulation domain.

the CHIMERE model following the approach described by Olivié et al. (2004) using the Tiedtke scheme (1989).

\section{Tracer simulation}

In this first experiment passive tracers are released at different heights in the troposphere. The objective is to quantify the fraction of these tracers transferred to the surface in a given time, and to identify possible transport pathways. Two summer periods (June-July-August) are simulated: summer 2003, known as one of the hottest and most polluted summers in the last decade, in terms of number of days with ozone alerts (Vautard et al., 2005 and references therein) while ozone levels in summer 2004 were close to normal from the point of view of air quality (EEA report, 2007).

\subsection{Methodology}

Passive tracers represent virtual species that are dynamically transported in the model but do not undergo chemical transformations. Here, their horizontal advection is calculated using the non diffusive and mass conserving PPM (Parabolic Piecewise Method) scheme (Colella and Woodward., 1984). Because tracers are designed to mimic ozone, dry deposition needs to be taken into account. The pseudo-resistance scheme developed by Wesely and Hicks (1977) is used in CHIMERE for ozone dry deposition. At this stage, chemical decay of ozone is not included, because free tropospheric ozone lifetime is in the order of weeks, thus long enough compared to the 4 day time period considered here. Within a pristine marine boundary layer ( $\mathrm{NOx}<50 \mathrm{ppt})$, net ozone loss of about $3 \mathrm{ppb} /$ day has been determined (Monks et al., 1998). Such loss rates could, to some extent, affect tracer concentrations. We will later discuss the impact of chemical loss for the IASI-like tracer experiment.

One of the crucial points of the experiment is the way tracers are initialised. The aim of this study is to identify to what 
Table 1. Characteristic top pressure $(\mathrm{hPa})$ and altitude $(\mathrm{km})$ associated to each model vertical level above sea level.

\begin{tabular}{cccccccccccccccccc}
\hline model level & 1 & 2 & 3 & 4 & 5 & 6 & 7 & 8 & 9 & 10 & 11 & 12 & 13 & 14 & 15 & 16 & 17 \\
\hline Pressure $(\mathrm{hPa})$ & 1008 & 998 & 983 & 960 & 925 & 874 & 797 & 708 & 623 & 546 & 476 & 414 & 359 & 310 & 266 & 227 & 200 \\
Altitude $(\mathrm{km})$ & 0.04 & 0.13 & 0.26 & 0.46 & 0.77 & 1.25 & 2.02 & 2.99 & 4.02 & 5.07 & 6.12 & 7.16 & 8.21 & 9.23 & 10.3 & 11.3 & 12.1 \\
\hline
\end{tabular}
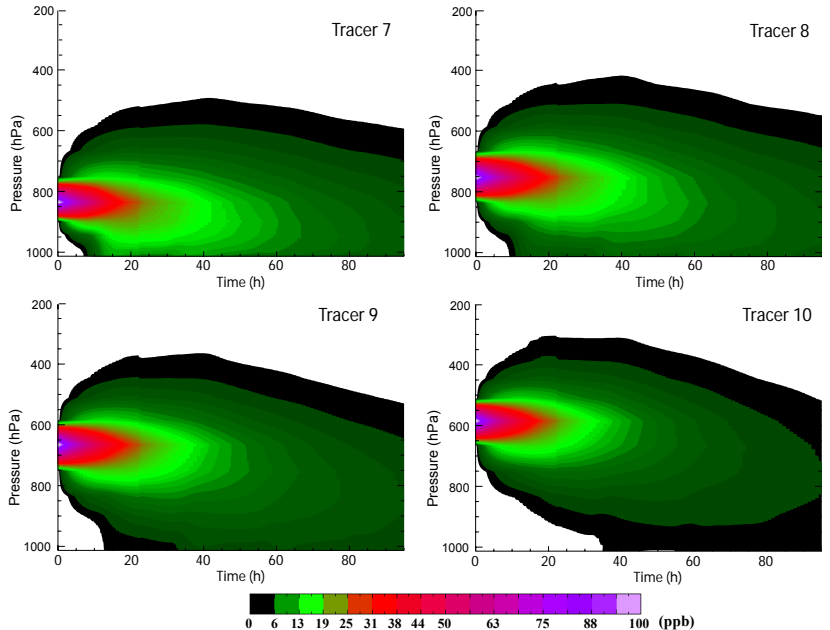

Fig. 2a. Time evolution (0-96h) of vertical tracer distributions in summer 2003 for tracer $7(860 \mathrm{hPa}-790 \mathrm{hPa})$, tracer $8(790 \mathrm{hPa}-$ $700 \mathrm{hPa})$, tracer $9(700 \mathrm{hPa}-620 \mathrm{hPa})$ and tracer $10(620 \mathrm{hPa}-$ $540 \mathrm{hPa})$. For each tracer, concentrations (ppb) have been averaged over the whole geographical domain and over 21 4-day time periods.

extent and at which time scale free tropospheric air masses are transported downwards to the surface. Here, we define one tracer for each vertical model level defined in Table 1 (i.e. 17 tracers). The concentration of each tracer is arbitrarily initialized to $100 \mathrm{ppb}$ in one vertical model level and to zero elsewhere. To follow the time evolution of tracer fields, 4-day periods are defined. Tracers are "released" (initialised) at the beginning of each period, at 00:00 UT, and reset to zero after $96 \mathrm{~h}$ (four days) of simulation. Longer time periods are of limited interest as most of the tracer will be swept off the geographical domain. One summer season is then split into 21 4-day periods. Results over these 21 time periods in each summer are averaged for each summer to obtain hourly transport statistics as a function of time after tracer release.

\subsection{Results}

\subsubsection{Summer average results}

Figure $2 \mathrm{a}$ and $\mathrm{b}$ displays the temporal evolution of four different tracers $(7,8,9$, and 10), averaged over the whole horizontal domain and over summer seasons 2003 or 2004.

For all tracers, a significant part reaches ground after a certain time of release. For tracer 7, initialized between 870
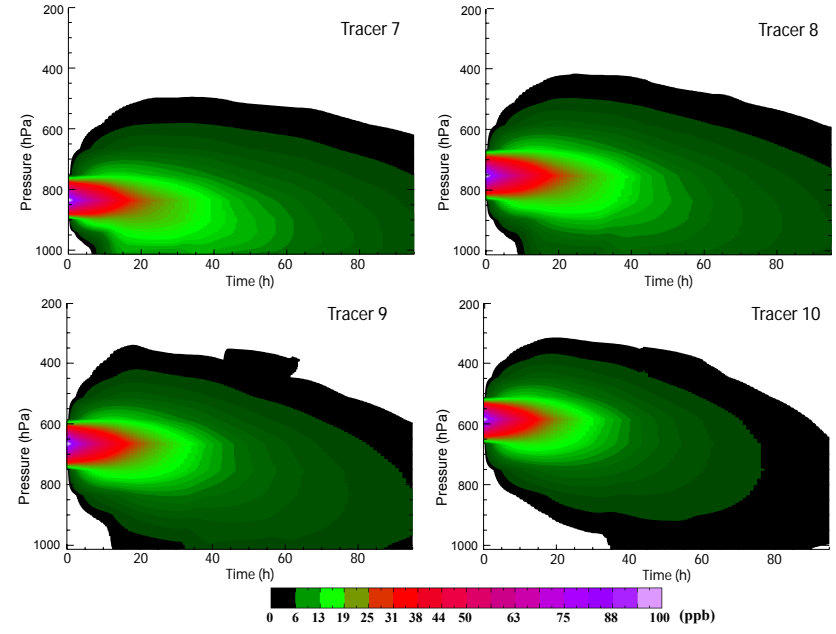

Fig. 2b. Same as Fig. 2a, but for summer 2004.

and $790 \mathrm{hPa}$ (for a grid point at sea level), maximum concentrations at ground (around $13 \mathrm{ppb}$ ) are observed already during the afternoon of the first day. For this tracer, entrainment into the rising convective boundary layer in the morning is an efficient transport mechanism, as indicated by the sharp concentration increase at ground at about 10:00 UT in both summers 2003 and 2004. Tracers 8, 9 and 10 that have been initialized below about $800 \mathrm{hPa}$ (i.e. above the top of the boundary layer most of the time) show slower downward transport. Maximum concentrations at ground for summer 2004 are observed after $32 \mathrm{~h}$ for tracer 8 (around $10 \mathrm{ppb}$ ), after $40 \mathrm{~h}$ for tracer 9 (around $6 \mathrm{ppb}$ ), and after $50 \mathrm{~h}$ for tracer 10 (below $5 \mathrm{ppb}$ ). For summer 2003, results are rather similar (Fig. 2). Thus, we can conclude that a significant fraction of free tropospheric air masses can reach the surface within two or three days. After that time tracer concentrations decrease at surface and also in the vertical, due to horizontal advection out of the domain and dry deposition to the ground.

Time evolution of concentrations for tracer 11 (initialized between 540 and $470 \mathrm{hPa}$, not shown in Fig. 2) also displays a general subsidence pattern, nevertheless concentrations above $900 \mathrm{hPa}$ remain near zero in all 4-day periods for both years. This is the case for all tracers initialized below $500 \mathrm{hPa}$. This indicates that no information from these levels will reach the surface within 4 days (at least for the given simulation domain).

In order to analyze horizontal patterns of downward transport, we examine (Fig. 3a and b) the horizontal distribution of 

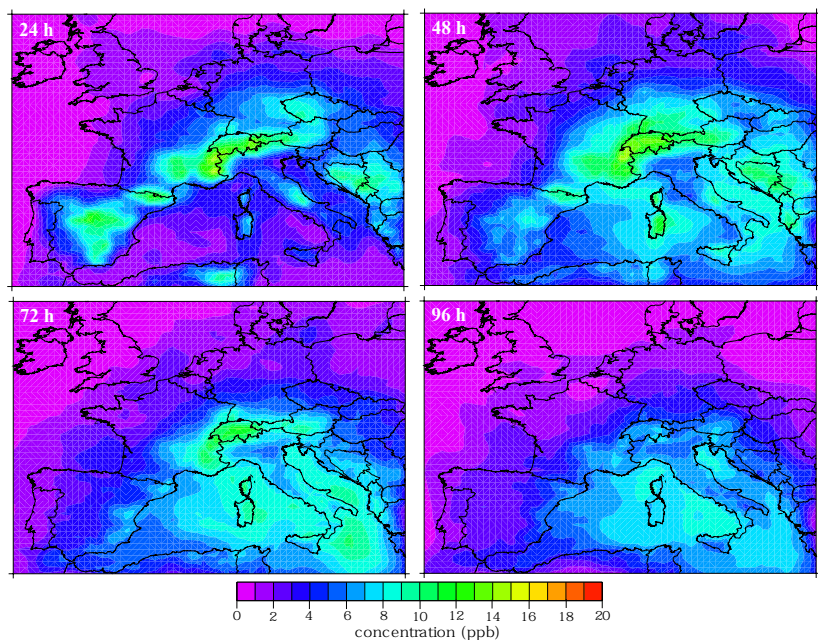

Fig. 3a. Surface concentrations for tracer number 8 (790-700 hPa) after 24, 48, 72 and $96 \mathrm{~h}$ of simulation, in summer 2003.
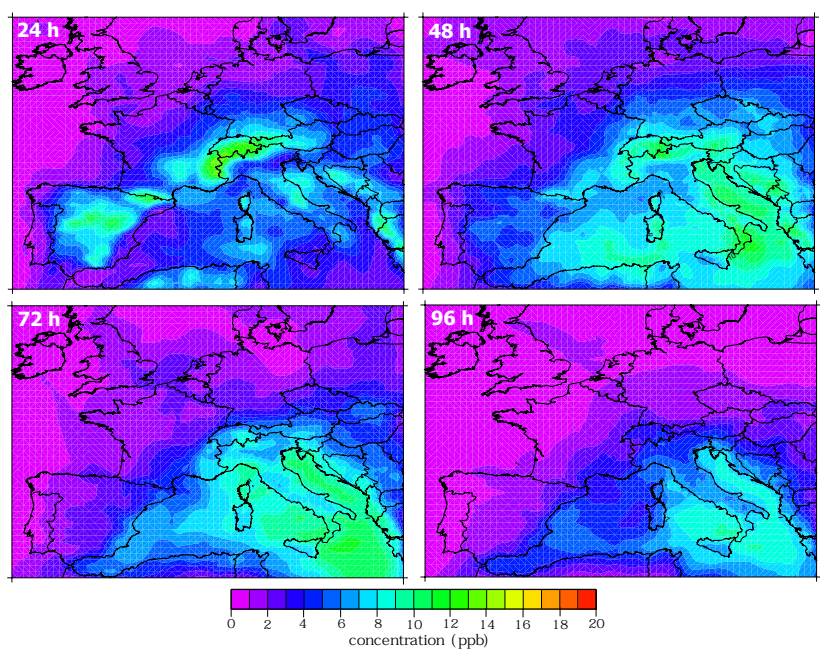

Fig. 3b. Same as Fig. 3a, but for summer 2004.

tracer 8 at the surface (originating in a model layer extending from about 2 to $3 \mathrm{~km}$ height a.s.l., in general above the boundary layer height). After $24 \mathrm{~h}$ of simulation its downward transport is significant especially over mountainous areas where its concentration can reach $15 \%$ of the initial value, also due to horizontal advection. Until 3 days, its concentrations remain important in particular over the Mediterranean basin reaching 5 to $12 \%$ of its initial concentrations. Concentrations after $96 \mathrm{~h}$ can still reach more than $5 \%$ of their initial values over the Mediterranean Sea and Italy. Observed patterns appear to be similar for summers 2003 (Fig. 3a) and 2004 (Fig. 3b). Very similar geographical patterns are also observed for tracers 7 to 10 .
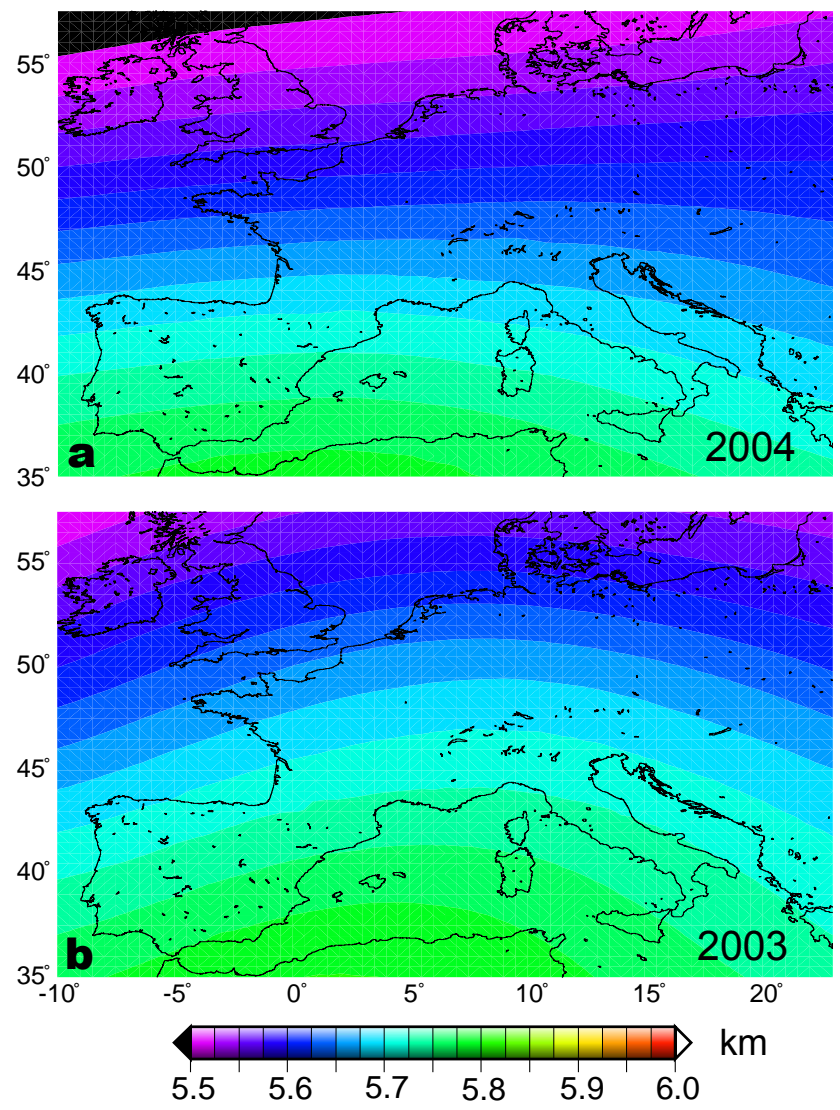

Fig. 4. Maps of the $500 \mathrm{hPa}$ geopotential height $(\mathrm{km})$ averaged over the whole summer of 2003 (a) and 2004 (b). Fields have been calculated by the Integrated Forecasting System (IFS) of the European center.

Results of this tracer experiment indicate that the transport of free-tropospheric air masses to the surface is more pronounced over the Mediterranean Sea. We now wish to analyse which type of transport phenomena are responsible for these features. Figure 4 show high values of geopotential height at $500 \mathrm{hPa}$ that take place over the Mediteranean area during summer. As mentioned previously, this classical features results of the north-eastern extension of the subtropical ridge that induce blocking and subsident anticyclonic conditions over the Mediteranean area. These stable anticyclonic conditions are often related to large scale subsident vertical motion which would then be responsible for the enhanced free tropospheric tracer concentrations near ground over the Mediterranean basin. To ascertain this hypothesis, we have first inspected the vertical velocity field over the European domain. We have calculated mean vertical velocities for each summer period (i.e. 2003 and 2004) at $700 \mathrm{hPa}$ from the meteorological fields produced by the Integrated Forecasting System of the ECMWF. Figure 5 shows that for both summers the Mediterranean basin is on the average dominated by downward vertical motion, especially in the 

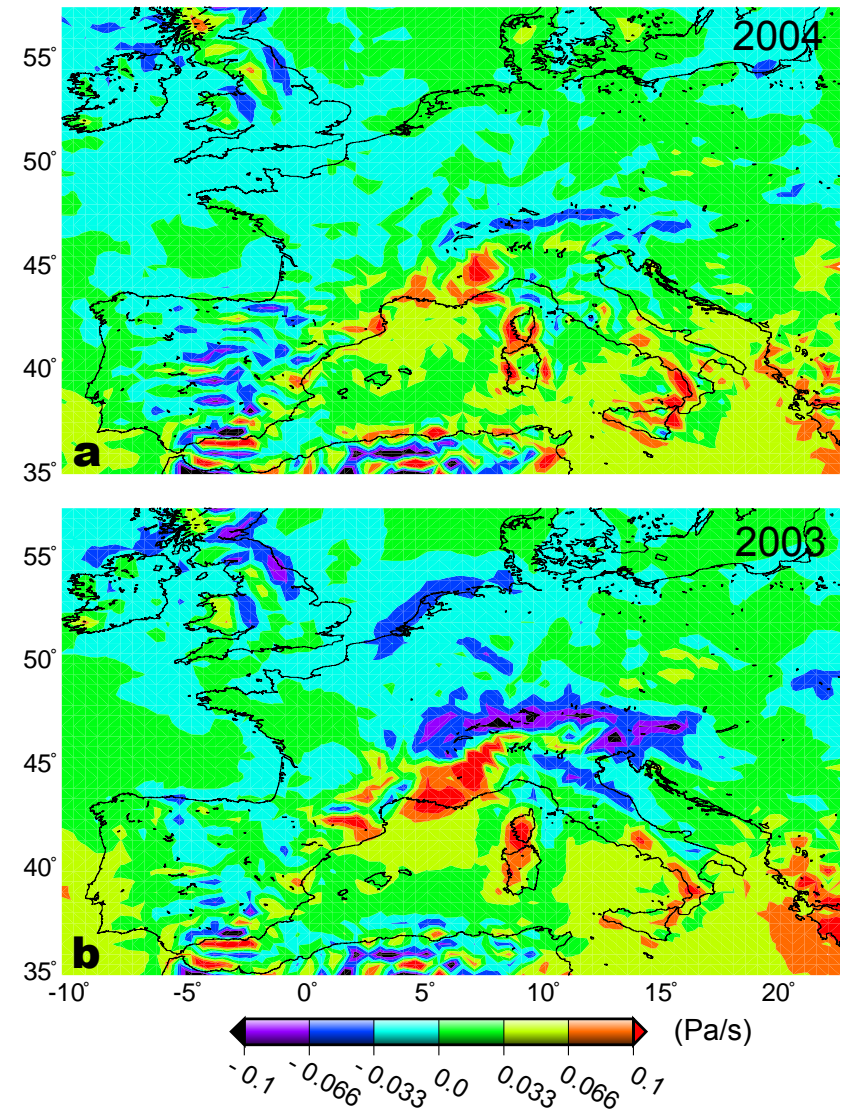

Fig. 5. Maps of vertical velocities $\left(\mathrm{Pa}_{\mathrm{s}}{ }^{-1}\right.$ ) at the $700 \mathrm{hPa}$ level averaged over the whole summer of 2003 (a) and 2004 (b). Fields have been calculated by the Integrated Forecasting System (IFS) of the European Center. Positive values indicate downward motion.

south-eastern part of the domain, south of Italy and Greece. To further substantiate the hypothesis that subsident motion is responsible for enhanced tracer levels at ground, we have calculated 4-day back trajectories using the Hysplit model (Draxler and Rolph, 2003) and taking NCEP meteorological fields as input data. Arrival points are London $\left(51.5^{\circ} \mathrm{N} ; 0^{\circ}\right)$, Prague $\left(50^{\circ} \mathrm{N} ; 14.5^{\circ} \mathrm{E}\right)$, Madrid $\left(40.5^{\circ} \mathrm{N} ; 3.7^{\circ} \mathrm{W}\right)$ and Roma $\left(42^{\circ} \mathrm{N} ; 12.5^{\circ} \mathrm{E}\right)$ respectively located near the center of the A, $\mathrm{B}, \mathrm{C}$ and $\mathrm{D}$ regions defined on Fig. 1. The back trajectories are initialized at 500 meters above ground at noon and have been calculated for each day of summers 2003 and 2004. Clearly air masses arriving at Roma undergo much more subsidence than those arriving at any other location (Fig. 6). For Roma, $65 \%$ of the trajectories are originating below $850 \mathrm{hPa}$ four days before, while they are less than $19 \%$ for London, $27 \%$ for Prague, and $15 \%$ for Madrid. For all locations, only few of the air masses (from below $850 \mathrm{hPa}$ ) originate outside the model domain within the 4-day time span $(6 \%$ for London, $5 \%$ for Prague, $1 \%$ for Madrid and less than $1 \%$ for Roma).
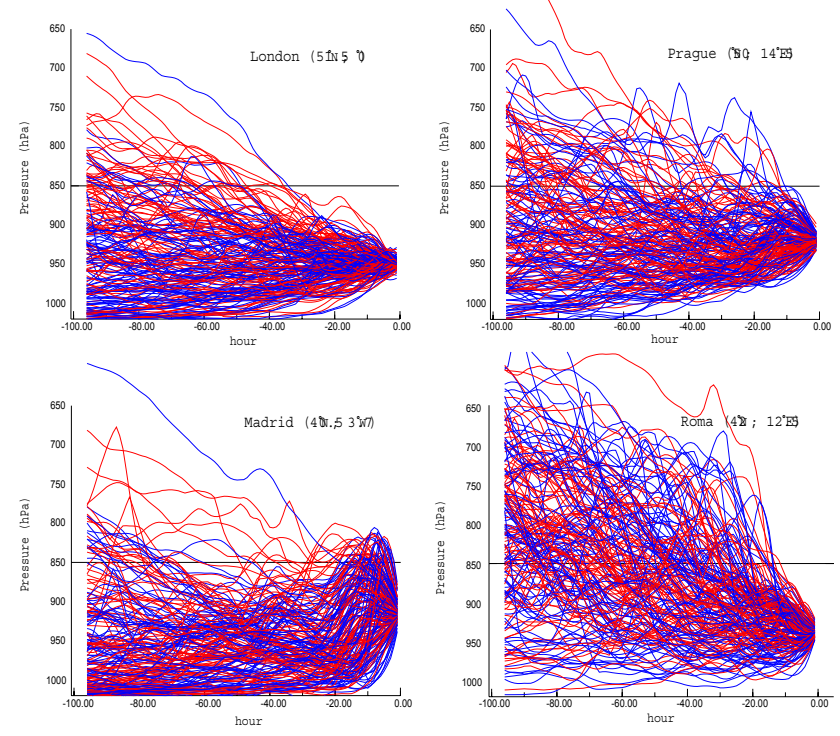

Fig. 6. Time evolution as a function of altitude (expressed in $\mathrm{hPa}$ ) for 4 days back-trajectories calculated at four European sites: London, Prague, Madrid, Roma. Back-trajectories have been calculated using the Hysplit model (Draxler and Rolph, 2003) for each day of summers 2003 (in red) and 2004 (in blue) from $500 \mathrm{~m}$ height above the ground at noon.

These results clearly confirm that the strongest subsidence, responsible for the enhanced free tropospheric tracer concentrations near ground, occurs over the Mediterranean basin, in the south-eastern part of the model domain (D region). They also show that the choice of the geographical domain and especially of its boundaries only slightly affects the validity of the result, since the big majority of back trajectories that underwent strong subsidence stays within the domain within four days, i.e. the downward transport takes place within the domain.

In addition to subsidence, also mixing within the convective boundary layer is an important transport mechanism at the lowest levels. Especially, in land areas bordering the Mediterranean Sea, the daily maxima of boundary layer heights can reach more than $2 \mathrm{~km}$ as diagnosed from ECMWF meteorology using the critical Richardson number profile. Thus, tracer downward transport to the surface appears to be a combination of advective subsidence transport and turbulent mixing. The altitude below which turbulent mixing is acting is strongly region dependant, below $1 \mathrm{~km}$ over the Mediterranean Sea, up to $2 \mathrm{~km}$ over Spain and Balkans for example.

\subsubsection{Time variability and case studies}

An important remaining question is, whether subsident motion leading to enhanced tracer levels at ground is continuous or of episodic nature. To answer this question, we have 

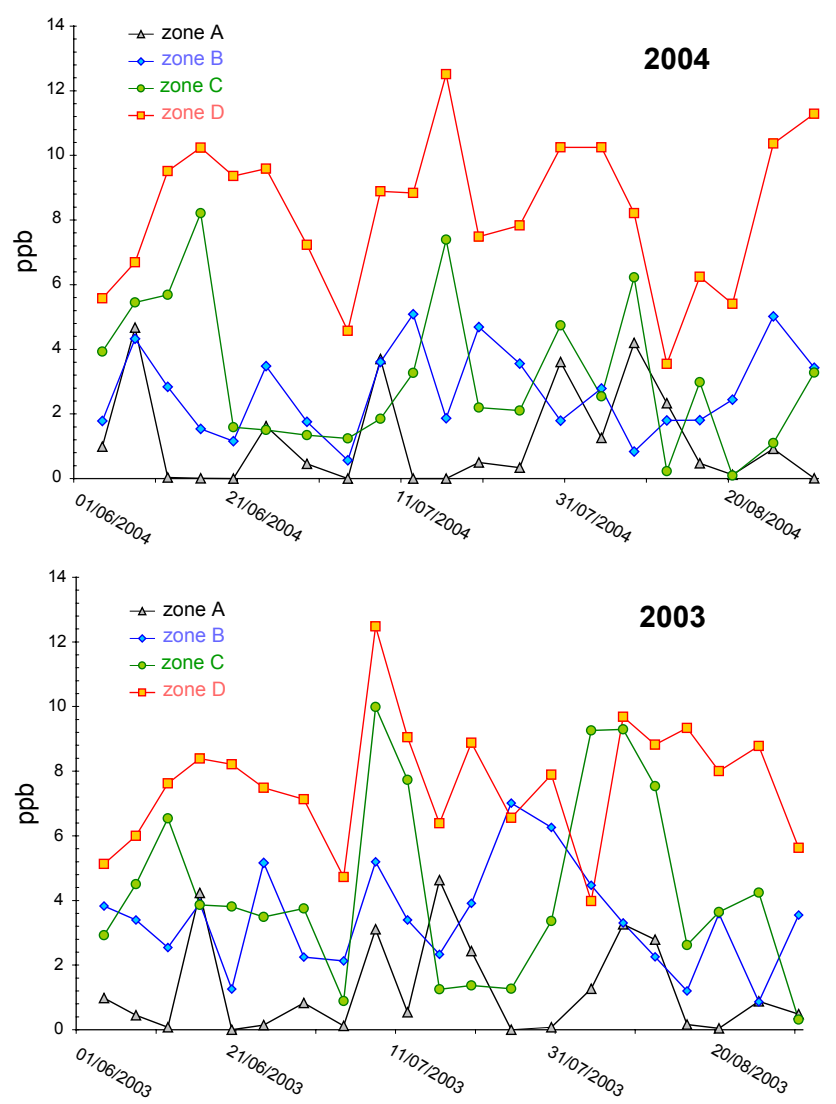

Fig. 7. Time evolution of tracer 8 surface concentrations ( $\mathrm{ppb}$ ) averaged over the A (black curve), B (blue curve), C (green curve) and D (red curve) domains (cf Fig. 1). Each point represents the surface tracer 8 concentration $72 \mathrm{~h}$ after release, for one of the 21 periods covering 2003 (lower panel) and 2004 (upper panel).

examined the variability of tracer concentrations at ground, and calculated the average tracer 8 concentrations in each of the A, B, C, D regions $72 \mathrm{~h}$ after release for each of the 4day period. Figure 7 shows the corresponding time series (i.e. values for the 21 time periods covering each summer) for 2003 and 2004. The most important concentrations are simulated for area $\mathrm{D}$, both on average $(\sim 8 \mathrm{ppb})$, but also for all individual days (with one exception) and the lowest for area A. For region D, tracer 8 levels vary from 4 to more than $12 \mathrm{ppb}$ with a standard deviation around $2 \mathrm{ppb}$. This relatively small standard deviation indicates that tracer downward transport to region D is a rather continuous feature, with some superimposed variability. For other regions, tracer variability is larger, from near one to respectively $10 \mathrm{ppb}$ in region $\mathrm{C}$ and to $7 \mathrm{ppb}$ in region $\mathrm{B}$. For region $\mathrm{A}$, tracer levels are always below $4 \mathrm{ppb}$. For regions $\mathrm{A}$ and $\mathrm{D}$, levels are similar for summers 2003 and 2004, for regions B and C, they are enhanced for summer 2003, which might be due to the more pronounced anticyclonic conditions over Western Europe for this period. The same analysis has been conducted
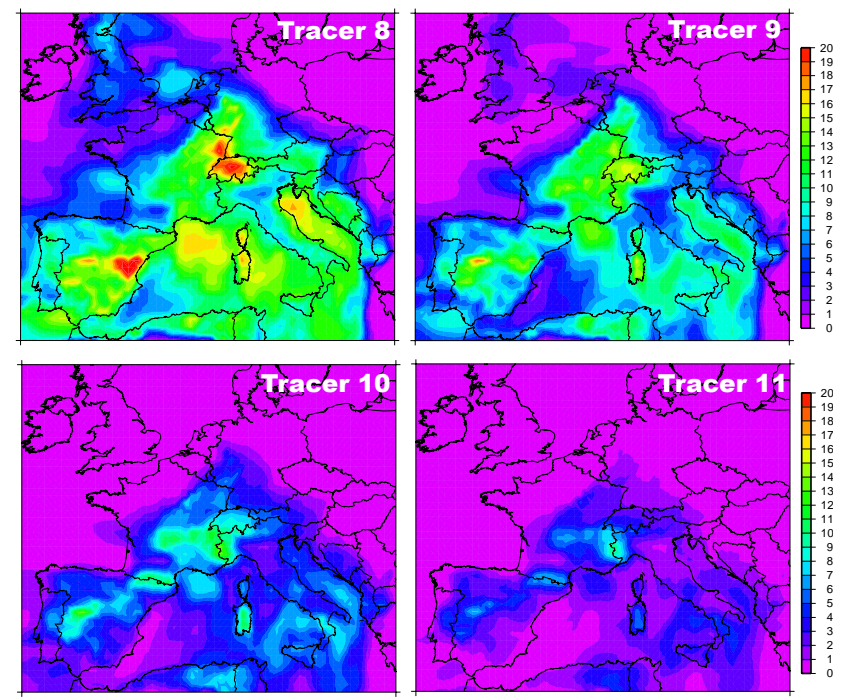

Fig. 8. Surface concentrations (ppb) for tracer number $8(\sim 790$ $700 \mathrm{hPa}), 9(\sim 700-620 \mathrm{hPa}), 10(\sim 620-550 \mathrm{hPa})$ and $11(\sim 550-$ $480 \mathrm{hPa}$ ) for 7 August 2003, $72 \mathrm{~h}$ after their release.

for tracer 9 (release between 3 and $4 \mathrm{~km}$ height). Results are similar (not shown) but show a slight reduction of the mean values. For example, average tracer 9 levels in area $\mathrm{D}$ are around $5 \mathrm{ppb}$ with a standard deviation of 1.8 .

Last, we consider the heat wave period in the first half of August 2003, when both subsident motion and an elevated boundary layer height might have contributed to enhanced tracer downward transport. For August 2003, Fig. 8 shows much larger than usual values of tracers $8,9,10,11$ (released between 800 and $480 \mathrm{hPa}$ ) at surface, three days after their release, and eastwards of an axis crossing Spain, Western France and the Benelux. During this period, a comparatively enhanced boundary layer height, up to $4 \mathrm{~km}$, was diagnosed over parts of Western Europe (Vautard et al., 2005). This might partly explain the enhanced tracer 8 and 9 surface levels, which are released below $4 \mathrm{~km}$, and then rapidly mix to the surface within the convective boundary layer. For tracers 10 and 11 , additional downward advection is necessary to explain the large values at surface.

Last, enhanced downward transport can also be illustrated for the time period when highest values of tracer 8 are simulated at the surface (Fig. 7). For the period of 4-8 July 2003, tracer 8 surface values up to $20 \mathrm{ppb}$ (i.e $20 \%$ of initial tracer values) are observed especially over the Mediterranean Sea (Fig. 9). In this case, back-trajectories calculated 4 days back and arriving for example at Lampedusa $\left(35.5^{\circ} \mathrm{N} ; 12.5^{\circ} \mathrm{E}\right)$ indicate that the air masses underwent very strong subsidence from around $600 \mathrm{hPa}$ to the surface.

All these results indicate that ozone observations provided by nadir IR sounders (sensitive to free-tropospheric ozone concentrations) can provide indirect information on surface ozone via subsident air mass transport from the free 


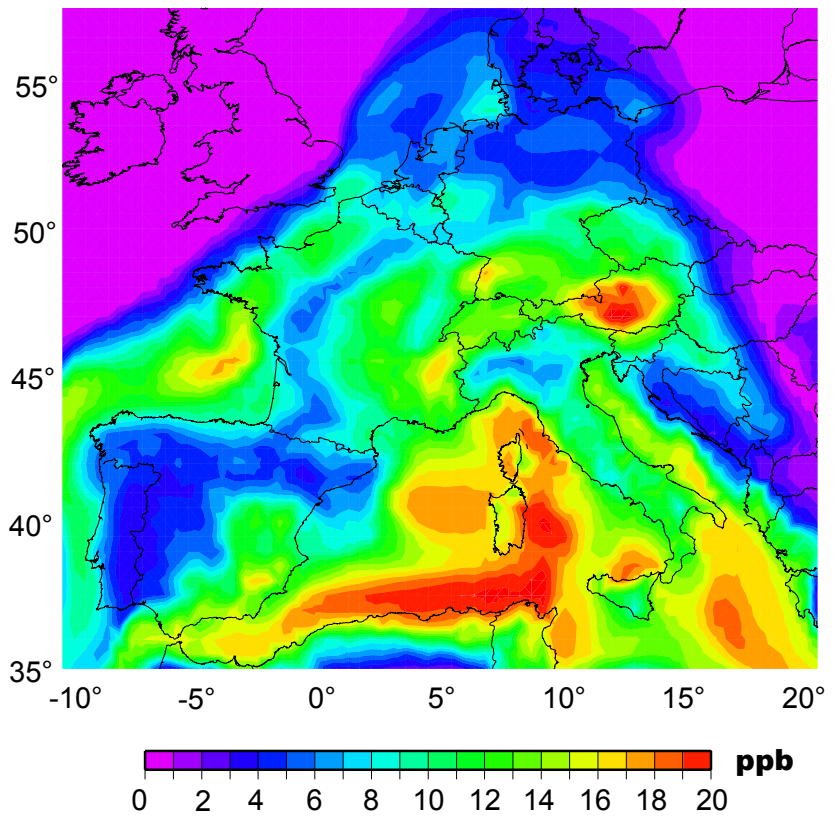

Fig. 9. Surface concentrations (ppb) for tracer number $8(\sim 790$ $700 \mathrm{hPa}$ ) for 7 July 2003, $72 \mathrm{~h}$ after their release.

troposphere to the surface especially over the Mediterranean Basin. This transport is a climatological phenomenon, but clearly also shows significant variability.

\section{IASI-like tracers}

\subsection{Methodology}

Instead of using several inert tracers each representative of only one vertical level (i.e one vertical fraction of the troposphere), we use now a single inert tracer that will mimic the new information obtained from nadir IR sounders like IASI (or TES). For this purpose, we define a tracer that will contain the additional information content obtained from an IASI-like estimation $\left(X_{\text {IASI }}\right)$ of the true state of the atmosphere, with respect to a corresponding estimation obtained from a model simulation $\left(X_{\mathrm{CHIMERE}}\right)$. In other words, the tracer will contain the additional information provided by the IASI instrument, in addition to the already available information from a model. In particular, this information will be exempt of the smoothing error, defined by Rodgers (2000). In the following, the mathematical construction of the tracer will be explained. Following Eq. (1) from Rodgers (2000, p. 47$)$, the retrieved profile $\hat{X}_{\text {IASI }}$ can be expressed as follows:

$\hat{X}_{\mathrm{IASI}}=\mathbf{A}\left(X_{\text {true }}-X_{a}\right)+X_{a}+\mathbf{G}_{y} \varepsilon_{y}$

where $X_{\text {true }}$ is the true ozone profile, $X_{a}$ represents the a priori profile used in the retrieval and $\mathbf{A}$ stands for the averaging kernel matrix that describes the sensitivity of the retrieval to the true state. $\mathbf{G}_{y}$ represents the gain matrix of the retrieval and $\varepsilon_{y}$ the observation error. The term $G_{y} \varepsilon_{y}$ will be neglected in the following making the hypothesis of an error free observation. The averaging kernel functions $\mathbf{A}$ indicates the altitude at which the satellite observations are sensitive to ozone. An element $\mathbf{A}_{i j}$ of $\mathbf{A}$ is defined as $\mathbf{A}_{i j}=\frac{d \hat{X}_{i}}{d X_{j}}$, i.e. as the sensitivity of a retrieval at level $i$ to the true state at level $j$. A is diagnosed during the retrieval process.

According to this formalism, IASI would retrieve a profile $\hat{X}_{\text {CHIMERE }}$ if the true state of the atmosphere was $X_{c h}$ (the profile simulated by the CHIMERE model):

$\hat{X}_{\text {CHIMERE }}=\mathbf{A}\left(X_{c h}-X_{a}\right)+X_{a}$

In other words $\hat{X}_{\text {CHIMERE }}$ corresponds to a simulated profile, but transformed in order to account for vertical resolution and sensitivity of the IASI instrument. It is this transformation (given by Eq. (2) in the text), which allows to avoid the smoothing error related to the observation, by making the simulated profile coherent with the observed one. Thus, the new information content given by the satellite measurement compared to the model estimation can be expressed as:

$\hat{X}_{\text {IASI }}-\hat{X}_{\text {CHIMERE }}=\mathbf{A}\left(X_{\text {true }}-X_{c h}\right)$

The right hand side of Eq. (3) represents the information provided by the observation in addition to our prior knowledge of the atmospheric state from a model, and this for an error free ideal case, i.e. neglecting the term $\mathbf{G}_{y} \varepsilon_{y}$ in Eq. (1). Thus, we use this formulation for our IR-sounder-like tracer $\left(X_{T}\right)$.

In order to calculate the tracer profiles $X_{A}$, we just need information on $A$ and on the term $X_{\text {true }}-X_{c h}$.

In our case, a retrieval method based on an altitudedependent regularization as described in Eremenko et al. (2008) was used to derive two sets of averaging kernels (for ozone) for medium range surface temperatures (between $15^{\circ} \mathrm{C}$ and $25^{\circ} \mathrm{C}$, left panel) and for high surface temperatures (more than $25^{\circ} \mathrm{C}$, right panel). These two averaging kernels are hereafter referred to as AVK_med and AVK_high. Each graph in Fig. 10 represents a IASI retrieval at a given height, and indicates its sensitivity to ozone at different levels (limited to the tropospheric part of the AVK's). For both averaging kernels sensitivity to PBL ozone is rather weak, it is maximum in the free troposphere from above around 3 to 4 kilometers height. Graphs for IASI measurements in the first kilometers of the atmosphere are superimposed, indicating that measurements are not independent. Indeed, from the trace of these matrices it can be derived that an independent piece of information can be obtained when integrating the measurements over the first 8 to $9 \mathrm{~km}$ of the troposphere (Eremenko et al., 2008). It should be noted that the low sensitivity of the IASI averaging kernels in the lower tropospheric layers results from atmospheric properties (low contrasts between air and surface temperature) and can be changed only 
Table 2. RMSE: Vertical profile of mean RMSE (ppb) calculated with commercial aircraft ozone measurements (MOZAIC) against simulated ozone concentrations from CHIMERE model. All data are interpolated to a $1 \mathrm{~km}$ vertical grid. Aircraft measurements (from landing and take-off phase) from two airports (Frankfurt and Paris) are used. This represents around 180 profiles in summer 2004 (June to August). IASI-like tracer derived for a medium $\left(X_{T \_ \text {med }}\right.$ and high $\left(X_{T \_ \text {max }}\right)$ temperature averaging kernel.

\begin{tabular}{lcccccccccccc}
\hline$Z(\mathrm{~km})$ & $0-1$ & $1-2$ & $2-3$ & $3-4$ & $4-5$ & $5-6$ & $6-7$ & $7-8$ & $8-9$ & $9-10$ & $10-11$ & $11-12$ \\
\hline RMSE $(\mathrm{ppb})$ & 12 & 9 & 10 & 11 & 12 & 14 & 18 & 23 & 42 & 80 & 90 & 100 \\
$X_{T \_ \text {med }}(\mathrm{ppb})$ & 4.5 & 9 & 13 & 17 & 21 & 24 & 28 & 31 & 35 & 40 & 45 & 49 \\
$X_{T \_ \text {max }}(\mathrm{ppb})$ & 4 & 8 & 12 & 16 & 20 & 24 & 28 & 31 & 36 & 41 & 46 & 50 \\
\hline
\end{tabular}

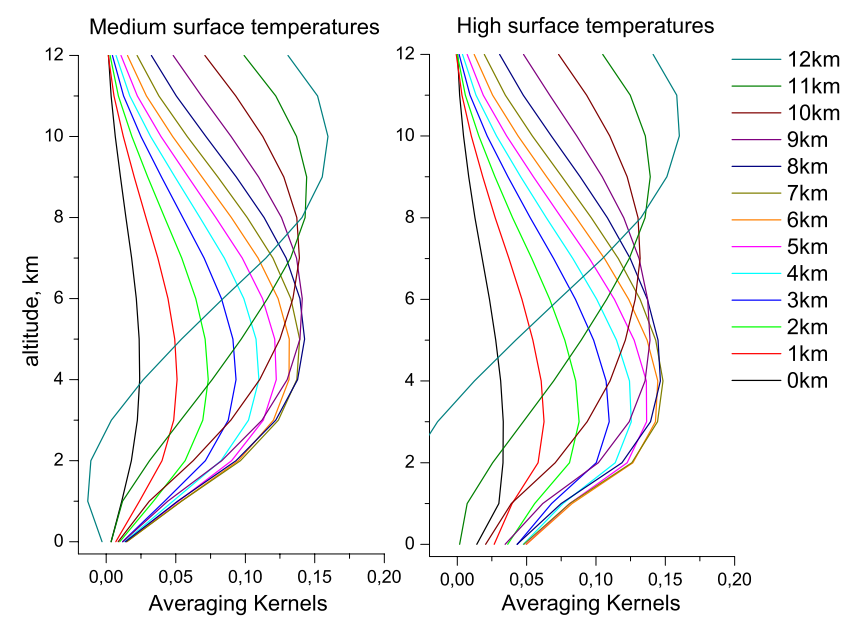

Fig. 10. IASI averaging kernels (Vectors of the $13 \mathrm{~km} \times 13 \mathrm{~km} \mathrm{~A}$ matrix) for European summer morning conditions. Averaging kernels for medium surface temperatures (between $15^{\circ} \mathrm{C}$ and $25^{\circ} \mathrm{C}$ are shown in the left panel and for high surface temperatures (above $25^{\circ} \mathrm{C}$ ) in the right panel.

slightly with use of other retrieval setups (Boynard et al., 2009; Keim et al., 2009). The following study is therefore valid for any IASI retrieval.

Next, we need to evaluate the term $X_{\text {true }}-X_{c h}$. Since the true ozone profile ( $\left.X_{\text {true }}\right)$ is not known, measured ozone vertical profiles are used as a proxy. Such profiles are routinely measured over Europe by onboard commercial aircraft in the frame of the MOZAIC program (Marenco et al., 1998). As an estimation of the difference between MOZAIC and CHIMERE ozone profiles, the root mean square (RMSE, Eq. 4) between both types of profiles is calculated.

RMSE $=\sqrt{\frac{1}{N} \sum_{i=1}^{N}\left(X_{\text {CHIMERE }}-X_{\text {MOZAIC }_{c}}\right)^{2}}$

The RMSE gives some more weight to large differences than the mean absolute difference. It has been calculated from around 180 MOZAIC profiles measured over Frankfurt and Paris airports during summer 2004 and the corresponding CHIMERE profiles.
The mean RMSE is calculated for each kilometer between surface and $12 \mathrm{~km}$ height (cf. Table 2) and averaging kernel matrices (AVK_med, AVK_high) are applied (following

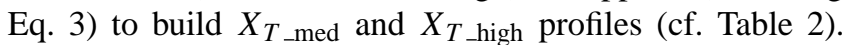
Initializing an inert tracer with these values allows following how this information is transported within the model and how it impacts simulated surface concentrations. Using AVK's for two different ranges of surface temperatures, the sensitivity variations in the averaging kernel functions is addressed. Table 2 shows that vertical profiles of both IASI-like inert tracers are very similar. In the following only results obtained using $X_{T \_ \text {med }}$ (obtained with AVK_med) will be discussed. Note that tracer values exceed values of corresponding RMSE between $3 \mathrm{~km}$ and $8 \mathrm{~km}$. This is due to the fact that model biases in the upper troposphere (that are rather important) are transferred to lower levels by off-diagonal elements of the averaging kernel matrix (which again reflects the limited resolution of the IASI instrument).

The inert tracer constructed this way is initialized each day at 10:00 UT (approximately the morning overpass of IASI instrument) uniformly over the domain, supposing an overall cloud free area. As the passive tracers before, dry deposition as for ozone is applied to the tracer. To analyse the results we have calculated an average over the 92 days of each simulated summer (i.e. 2003 and 2004).

\subsection{Results and discussion}

Figure 11 displays surface concentrations of the $X_{T \_ \text {med }}$ tracer at 6 and 18:00 UT and for both simulated years. As expected, highest concentrations are present over the Mediterranean basin and the Alps. They can reach $24 \mathrm{ppb}$ at 06:00 UT in 2003 and slighty lower values (22 ppb) in 2004. At 18:00 UT, higher surface concentrations are simulated (maxima up to 30 and $26 \mathrm{ppb}$ for 2003 and 2004 respectively). This is due to the new information provided by the simulated morning passage of IASI over the domain. Such values can represent between 20 to $40 \%$ of mean surface ozone concentrations.

In Sect. 3.1, we have made the hypothesis that we could neglect the chemistry so that tracers were considered as inert. For the case of the IASI-like tracer that is used to gain 

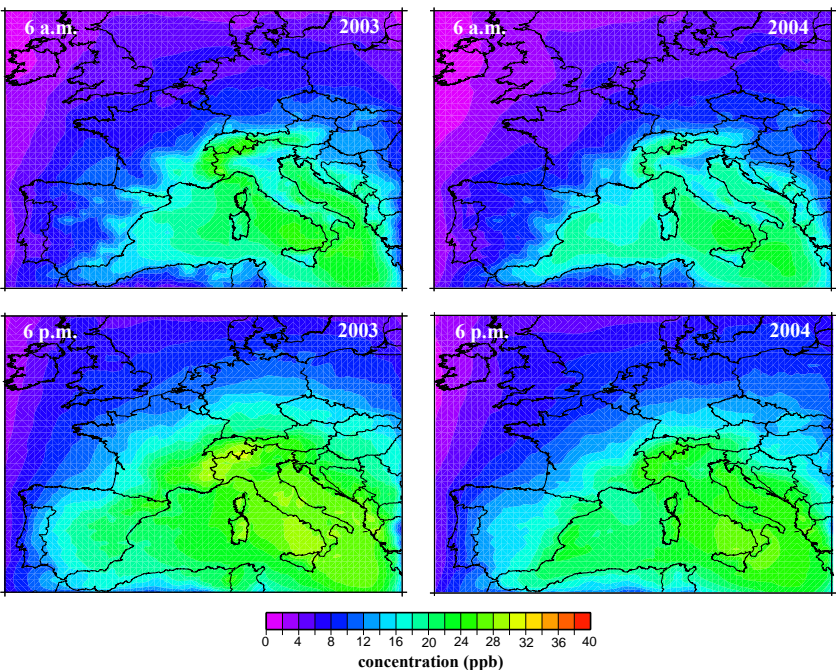

Fig. 11. Concentrations of a tracer with IASI-like vertical profile shape. The tracer is updated every morning at each satellite passage. Daily tracer concentrations are then calculated for the whole summer period (92 days). Concentrations at (a) 06:00 UT and (b) 18:00 UT for the summer 2003 (in the left panel) and 2004 (in the right panel) are shown.

more quantitative information, we have chosen to test this hypothesis. To do so, we have added the major chemical loss terms for ozone considered in the CHIMERE model in the IASI-like tracer simulation:

$$
\begin{aligned}
& \mathrm{O}_{3}+h v(\lambda<320 \mathrm{~nm}) \rightarrow 2 \mathrm{OH} \\
& \mathrm{O}_{3}+\mathrm{OH} \rightarrow \mathrm{HO}_{2}+\mathrm{O}_{2} \\
& \mathrm{O}_{3}+\mathrm{HO}_{2} \rightarrow \mathrm{OH}+2 \mathrm{O}_{2}
\end{aligned}
$$

Note that Eq. (5) gives the combined reaction of ozone photolysis and reaction of $\mathrm{O}\left({ }^{1} \mathrm{D}\right)$ with water vapour forming $\mathrm{OH}$. Results of this experiment show (Fig. 12) that the additional chemical loss term tend to reduce the tracer concentrations at the surface by around 20\% over the Mediterranean Basin where its concentrations are largest.

As a conclusion, IASI-like tropospheric ozone observations could constitute an efficient indirect constraint to correct simulated surface ozone concentrations. Nevertheless, this conclusion should be tempered considering some of the hypotheses that have been made for our calculation. Since we have supposed that no clouds were present, we have overestimated the potential correction given by the satellite. In addition, if IASI observations were assimilated in an atmospheric model, one would need to take into account the observational error, with the effect that the new satellite information would only partially be used for model correction. Thus, clearly, the results correspond to an upper limit of the possible constraint provided by IASI observations. Still, it is interesting
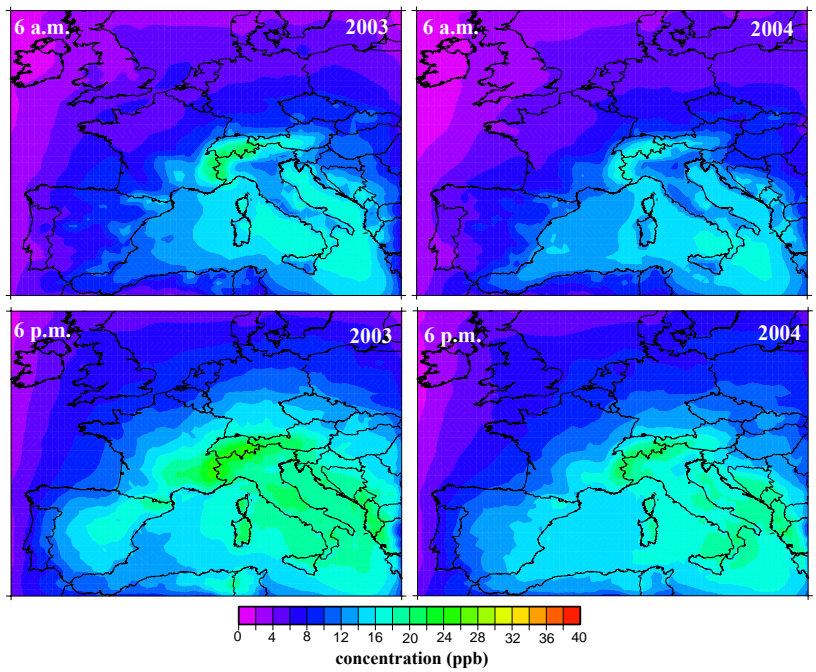

Fig. 12. Same as Fig. 11 for the simulation taking into account the chemical loss terms.

to note, that the spatial distribution of IASI-like tracer concentration fields at surface are similar to that of free tropospheric tracers considered in Sect. 3, with maximum values in the Mediterranean in the south-eastern part of the model domain. Again, the downward transport of free tropospheric air masses over the northern and the north-western part of the domain remains low, indicating that IASI-like observations are less efficient to constrain modelled surface ozone concentrations in these regions.

\section{Conclusions}

A tracer study has been performed in order to evaluate the potential constraint of ozone observations from nadir viewing infrared sounders like IASI or TES on near surface ozone. As these instruments show high sensitivity in the free troposphere, but low sensitivity near ground, a key question to be answered is which amount of information gained on free tropospheric ozone is transferred to ground through vertical transport processes. Two types of tracers have been introduced into the CHIMERE chemistry transport model in order to tackle this question: a passive tracer for each vertical model level, but which undergoes dry deposition at ground, and a tracer designed to mimic information contained in IASI ozone profile retrievals. This tracer study is a pre-study and highly complementary to actual data assimilation, for which "success" will depend on a number of factors difficult to distinguish (e.g. observation errors, model errors, and actual observation - model differences).

Within the European model domain, and within a time span of 4 days, tracers are transported to the surface only if they are initialised above $500 \mathrm{hPa}$. For tracers emitted between 800 and $700 \mathrm{hPa}$, an average of about $7 \%$ reaches the 
surface within a time span from a half to three days. After three days, surface concentrations of this tracer decrease, because of advection out of the domain. The three day time scale of decay of information is larger than that was observed for assimilation of surface ozone measurements (Elbern et al., 2001; Blond et al., 2004) where the benefit of assimilation decayed rapidly during the first day. This underlines the potential benefit of free tropospheric in addition to surface ozone observations. Free tropospheric tracer levels at surface are largest (up to 15\%) over mountain regions (trivial result) and over the south-east Mediterranean basin in the model domain. This is consistent with strong subsidence over the Eastern Mediterranean sea, related to persistent anticyclonic conditions during summer in combination with turbulent mixing in the boundary layer that can reach up to $2 \mathrm{~km}$ over land areas neighbouring the Mediterranean Sea. This subsident motion is made evident by trajectory calculations. Trajectory calculations also show that downward transport takes places within the model domain within a 4day time span, as only few trajectories (leave) the model domain during this period. On the contrary, tracer levels are very small over North-Western Europe. Results for years 2003 and 2004 with rather different meteorological conditions appear to be very similar. The question was tackled, if downward transport was continuous or episodic in nature. While it appeared rather continuous for the Mediterranean (south-eastern part of the model domain) sector, it appeared more episodic over the rest of the domain (i.e for sectors A, $\mathrm{B}$ and $\mathrm{C})$. A specific case was observed during the heatwave in summer 2003, when elevated boundary layer heights and subsident motion allowed rapid vertical mixing of free tropospheric tracers down to the ground. Clearly, the potential of IASI like observations to constrain surface ozone will be strongly affected by the presence of subsident motion. These results are confirmed by using additional tracer simulations designed to mimic additional (with respect to model simulations) information that would be delivered by a IASI type instrument. This tracer especially takes into account the instrument's vertical sensitivity (averaging kernel) largest in the free troposphere. Maximum tracer levels at surface occur again over the Mediterranean region in the south-eastern part of the model domain. As a general conclusion, this study shows the strong potential of IASI derived ozone profiles mainly sensitive to the free tropospheric ozone, to constrain modelled surface ozone levels over Europe, but with important geographical and temporal differences. To our knowledge, this is the most detailed work to quantify free tropospheric to surface tracer transport over Europe. It also confirms results obtained over US from assimilation of TES ozone profiles (Parrington et al., 2009), where the largest impact on surface ozone was also found over a region (SouthWestern US) with strongly subsident motion.
Acknowledgements. IASI has been developed and built under the responsibility of the Centre National d'Etudes Spatiales (CNES, France). It is flown onboard the METOP satellite as part of the EUMETSAT polar system. The IASI L1 data are received from the EUMETCast near real-time data distribution service. The French Space Agency CNES is acknowledged for support through the IASI/TOSCA project as well as the Ether French atmospheric database (http://ether.ipsl.jussieu.fr) for providing IASI data. This work has been supported by the University Paris12 (young researcher program) and the National French program LEFE. The authors acknowledge for the strong support of the European Commission, Airbus, and the Airlines (Austrian-Airlines, Austrian, Air France) who carry free of charge the MOZAIC equipment and perform the maintenance since 1994. MOZAIC is presently funded by INSU-CNRS, Meteo-France, and FZJ (Forschungszentrum Julich, Germany). The authors gratefully acknowledge the NOAA Air Resources Laboratory (ARL) for the provision of the HYSPLIT transport and dispersion model and/or READY website (http://www.arl.noaa.gov/ready.html) used in this publication. Lastly, the authors also acknowledge L. Menut for all his fruitful comments on the manuscript.

Edited by: T. Wagner

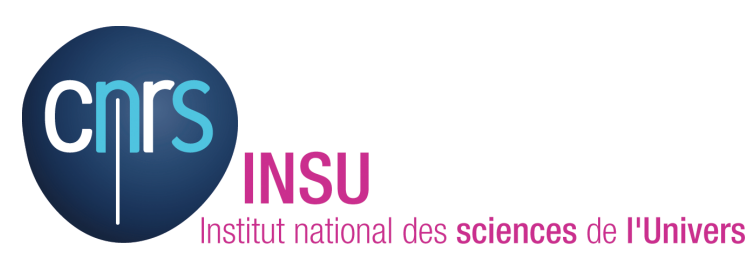

The publication of this article is financed by CNRS-INSU.

\section{References}

Beer, R.: TES on the Aura mission: Scientific objectives, measurements and analysis overview, IEEE Trans. Geosci. Remote Sens., 44(5), 1102-1105, 2006.

Bessagnet, B., Menut, L., Aymoz, G., Chepfer, H., and Vautard, R.: Modeling dust emissions and transport within Europe: The Ukraine March 2007 event, J. Geophys. Res., 113, D15202, doi:10.1029/2007JD009541, 2008.

Blond, N. and Vautard R.: Three-dimensional ozone analyses and their use for short-term ozone forecasts, J. Geophys. Res., 109, D17303, doi:10.1029/2004JD004515, 2004.

Boisgontier, B., Mallet, V., Berroir, J. P., Bocquet, M., Herlin, I., and Sportisse, B.: Satellite data assimilation for air quality forecast, Simul. Model. Pract. Th., 16, 1541-1545, 2008.

Boynard, A., Clerbaux, C., Coheur, P.-F., Hurtmans, D., Turquety, S., George, M., Hadji-Lazaro, J., Keim, C., and Meyer-Arnek, J.: Measurements of total and tropospheric ozone from IASI: comparison with correlative satellite, ground-based and ozonesonde observations, Atmos. Chem. Phys., 9, 6255-6271, 2009, http://www.atmos-chem-phys.net/9/6255/2009/.

Clerbaux, C., Hadji-Lazaro, J., Turquety, S., George, M., Coheur, P.-F., Hurtmans, D., Wespes, C., Herbin, H., Blumstein, D., Tournier, B., and Phulpin, T.: The IASI/MetOp I Mission: 
First Observations and Highlights of its Potential Contribution to GMES, COSPAR Inf. Bul., Vol. 2007, 19-24, 2007.

Coheur, P.-F., Barret, B., Turquety, S., Hurtmans, D., Hadji-Lazaro, J., and Clerbaux, C.: Retrieval and characterization of ozone vertical profiles from a thermal infrared nadir sounder, J. Geophys. Res., 110, D24303, doi:10.1029/2005JD005845, 2005.

Colella P. and Woodward, P. R.: The Piecewise Parabolic Method (PPM) for Gas-Dynamical Simulations, J. Comput. Phys., 54, 174-201, 1984.

Coll, I., Pinceloup, S., Perros, P. E., Laverdet, G., and Le Bras, G.: $3 \mathrm{D}$ analysis of high ozone production rates observed during the ESCOMPTE campaign, Atmos. Res., 477-505, 2005.

Cotton, W. R., Alexander, G. D., Hertenstein, R., Walko, R. L., McAnelly, R. L., and Nicholls, M.: Cloud venting - A review and some new global annual estimates, Earth-Sci. Rev., 39, 169206, 1995.

Dacre, H. F., Gray, S. L., and Belcher, S. E.: A case study of boundary layer ventilation by convection and coastal processes, J. Geophys. Res., 112, D17106, doi:10.1029/2006JD007984, 2007.

Deeter, M. N., Edwards, D. P., Gille, J. C., and Drummond, J. R.: Sensitivity of MOPITT observations to carbon monoxide in the lower troposphere, J. Geophys. Res., 112, D24306, doi:10.1029/2007JD008929, 2007.

Deguillaume, L., Beekmann, M., and Derognat, C.: Uncertainty evaluation of ozone production and its sensitivity to emission changes over the Ile-de-France region during summer periods, J. Geophys. Res., 113, D02304, doi:10.1029/2007JD009081, 2008.

Doherty, R. M., Stevenson, D. S., Collins, W. J., and Sanderson, M. G.: Influence of convective transport on tropospheric ozone and its precursors in a chemistry-climate model, Atmos. Chem. Phys., 5, 3205-3218, 2005, http://www.atmos-chem-phys.net/5/3205/2005/.

Draxler, R. R. and Rolph, G. D.: HYSPLIT (HYbrid Single-Particle Lagrangian Integrated Trajectory) Model access via NOAA ARL READY Website (http://www.arl.noaa.gov/ready/hysplit4.html), NOAA Air Resources Laboratory, Silver Spring, MD, 2003.

Elbern, H. and Schmidt, H.: Ozone episode analysis by fourdimensional variational chemistry data assimilation, J. Geophys. Res., 106, 3569-3590, 2001.

Eremenko, M., Dufour, G., Foret, G., Keim, C., Orphal, J., Beekmann, M., Bergametti, G., and Flaud, J.-M.: Tropospheric ozone distributions over Europe during the heat wave in July 2007 observed from infrared nadir spectra recorded by IASI, Geophys. Res. Lett., 35, L18805, doi:10.1029/2008GL034803, 2008.

Fiore, A. M., Jacob, D. J., Bey, I., Yantosca, R. M., Field, B. D., and Fusco, A. C.: Background ozone over the United States in summer: Origin, trend, and contribution to pollution episodes, J. Geophys. Res., 107, 4275, doi:10.1029/2001JD000982, 2002.

Forêt, G., Flamant, C., Cautenet, S., Pelon, J., Minvielle, F., Taghavi, M., and Chazette, P.: The structure of the haze plume over the Indian Ocean during INDOEX: tracer simulations and LIDAR observations, Atmos. Chem. Phys., 6, 907-923, 2006, http://www.atmos-chem-phys.net/6/907/2006/.

Hauglustaine, D. A., Hourdin, F., Walters, S., Jourdain, L., Filiberti, M.-A., Larmarque, J.-F., Holland, E. A.: Interactive chemistry in the Laboratoire de Météorologie Dynamique general circulation model: description and background tropospheric chemistry evaluation, J. Geophys. Res., 109, D04314, doi:10.1029/2003JD003957, 2004.
Henne, S., Dommen, J., Neininger, B., Reimann, S., Staehelin, J., and Prévôt, A. S. H.: Influence of mountain venting in the Alps on the ozone chemistry of the lower free troposphere and the European pollution export, J. Geophys. Res., 110, D22307, doi:10.1029/2005JD005936, 2005.

Hodzic, A., Vautard, R., Chepfer, H., Goloub, P., Menut, L., Chazette, P., Deuzé, J. L., Apituley, A., and Couvert, P.: Evolution of aerosol optical thickness over Europe during the August 2003 heat wave as seen from CHIMERE model simulations and POLDER data, Atmos. Chem. Phys., 6, 1853-1864, 2006, http://www.atmos-chem-phys.net/6/1853/2006/.

Honoré, C., Rouil, L., Vautard, R., Beekmann, M., Bessagnet, B., Dufour, A., Elichegaray, C., Flaud, J.-M., Malherbe, L., Meleux, F., Menut, L., Martin, D., Peuch, A., Peuch, V.-H., and Poisson, N.: Predictability of European air quality: Assessment of 3 years of operational forecasts and analyses by the PREVAIR system, J. Geophys. Res., 113, D04301, doi:10.1029/2007JD008761, 2008.

Kalabokas, P. D., Mihalopoulos, N., Ellul, R., Kleanthous, S., and Repapis, C. C.: An investigation of the meteorological and photochemical factors influencing the background rural and marine surface ozone levels in the Central and Eastern Mediterranean, Atmos. Environ., 42, 7894-7906, 2008.

Keim, C., Eremenko, M., Orphal, J., Dufour, G., Flaud, J.-M., Höpfner, M., Boynard, A., Clerbaux, C., Payan, S., Coheur, P.F., Hurtmans, D., Claude, H., Dier, H., Johnson, B., Kelder, H., Kivi, R., Koide, T., López Bartolomé, M., Lambkin, K., Moore, D., Schmidlin, F. J., and Stübi, R.: Tropospheric ozone from IASI: comparison of different inversion algorithms and validation with ozone sondes in the northern middle latitudes, Atmos. Chem. Phys. Discuss., 9, 11441-11479, 2009,

http://www.atmos-chem-phys-discuss.net/9/11441/2009/.

Kowol-Santen, J., Beekmann, M., Schmitgen, S., and Dewey, K.: Tracer analysis of transport from the boundary layer to the free troposphere, Geophys. Res. Lett., 28, 2907-2910, 2001.

Lawrence, M. G. and Rasch, P. J.: Tracer transport in deep convective updrafts: plume ensemble versus bulk formulations, J. Atmos. Sci., 62, 2880-2894, 2005.

Lelieveld, J., Berresheim, H., Borrmann, S., et al.: Global Air Pollution Crossroads over the Mediterranean, Science, 298, doi:10.1126, 2002.

Marenco, A., Thouret, V., Nédélec, P., Smit, H., Helten, M., Kley, D., Karcher, F., Simon, P., Law, K., Pyle, J., Poschmann, G., von Wrede, R., Hume, C., and Cook, T.: Measurement of ozone and water vapor by Airbus in-service aircraft: The MOZAIC airborne program, An overview, J. Geophys. Res., 103, 25631-25642, 1998.

Monks, P. S., Carpenter, L. J., Penkett, S. A., Ayers, G. P., Gillett, R. W., Galbally, I. E., and Meyer, C. P.: Fundamental ozone photochemistry in the remote marine boundary layer the soapex experiment, measurement and theory, Atmos. Environ., 32, 36473664, 1998.

Olivié, D. J. L., van Velthoven, P. F. J., Beljaars, A. C. M., and Kelder, H. M.: Comparison between archived and off-line diagnosed convective mass fluxes in the chemistry transport model TM3, J. Geophys. Res., 109, D11303, doi:10.1029/2003JD004036, 2004.

Parrington, M., Jones, D. B. A., Bowman, K. W., Horowitz, L. W., Thompson, A. M., Tarasick, D. W., and Witte, J. C.: Estimating the summertime tropospheric ozone distribution over North 
America through assimilation of observations from the Tropospheric Emission Spectrometer, J. Geophys. Res., 113, D18307, doi:10.1029/2007JD009341, 2008.

Parrington, M., Jones, D. B. A., Bowman, K. W., Thompson, A. M., Tarasick, D. W., Merrill, J., Oltmans, S. J., Leblanc, T., Witte, J. C., and Millet, D. B.: Impact of the assimilation of ozone from the Tropospheric Emission Spectrometer on surface ozone across North America, Geosphys. Res. Lett., 36, L04802, doi:10.1029/2008GL036935, 2009.

Rodgers, C. D.: Inverse Methods for Atmospheric Sounding : Theory and Practice, World Scientific, Series on Atmospheric, Oceanic and Planetary Physics, 2, Hackensack, N. J., 2000.

Rouil, L., Honoré, C., Vautard, R., Beekmann, M., Bessagnet, B., Malherbe, L., Meleux, F., Dufour, A., Elichegaray, C., Flaud, J.-M., Menut, L., Martin, D., Peuch, A., Peuch, V.-H. and Poisson, N.: Prev'air: An Operational Forecasting and Mapping System for Air Quality in Europe, B. Am. Meteorol. Soc., 90, doi: 10.1175/2008BAMS239, 2009.

Sinclair, V. A., Gray, S. L., and Belcher, S. E.: Boundary-layer ventilation by baroclinic life cycles, Q. J. R. Meteorol. Soc., 134, 1409-1424, 2008.

Szopa, S., Foret, G., Menut, L., and Cozic, A.: Impact of large scale circulation on European summer surface ozone: consequences for modelling forecast, Atmos. Environ., 43, 1189-1195, 2009.

Tiedtke, M.: A comprehensive mass flux scheme for cumulus parameterization in large-scale models, Mon. Weather Rev., 117, 1779-1800, 1989.

Traub, M., Fischer, H., de Reus, M., Kormann, R., Heland, H., Ziereis, H., Schlager, H., Holzinger, R., Williams, J., Warneke, C., de Gouw, J., and Lelieveld, J.: Chemical characteristics assigned to trajectory clusters during the MINOS campaign, Atmos. Chem. Phys., 3, 459-468, 2003,

http://www.atmos-chem-phys.net/3/459/2003/.
Vautard, R., Honore, C., Beekmann, M., and Rouil, L.: Simulation of ozone during the August 2003 heat wave and emission control scenarios, Atmos. Environ., 39, 2957-2967, 2005.

Vestreng, V., Breivik, K., Adams, M., Wagener, A., Goodwin, J., Rozovskkaya, O., and Pacyna, J. M.: Inventory Review 2005, Emission Data reported to LRTAP Convention and NEC Directive, Initial review of HMs and POPs, Technical report MSC-W 1/2005, ISSN 0804-2446, 2005.

Wesely, M. L. and Hicks, B. B.: Some factors that affect the deposition rates of sulfur dioxide and similar gases on vegetation, J. Air Pollut. Control Ass., 27, 1110-1116, 1977.

Xoplaki, E.: Climate variability over the Mediterranean, PhD thesis, University of Bern, Switzerland, (http://www.giub.unibe.ch/ klimet/docs/phd_xoplaki.pdf), 2000.

Ziv, B., Saaroni, H. and Alpert, P.: The factors governing the summer regime over the eastern Mediterranean, Int. J. Climatol., 24, 1859-1871, 2004. 